\title{
Plant bio-stimulator fertilizers can be applied in integrated plant management (IPM) in forest nurseries
}

\author{
Miłosz Tkaczyk ${ }^{1} \bowtie$, Justyna A. Nowakowska ${ }^{2}$, Tomasz Oszako ${ }^{1,3}$ \\ ${ }^{1}$ Forest Research Institute, Department of Forest Protection, Sękocin Stary, Braci Leśnej 3, 05-090 Raszyn, Poland, e-mail: \\ M.Tkaczyk@ibles.waw.pl \\ ${ }^{2}$ Forest Research Institute, Laboratory of Molecular Biology, Sękocin Stary, Braci Leśnej 3, 05-090 Raszyn, Poland \\ ${ }^{3}$ Technical University in Białystok, Forest Faculty, Piłsudskiego 8, 17-200 Hajnówka, Poland
}

\section{Abstract}

In the circumstances of only a limited number of pesticides being approved for use in forest nurseries, it is necessary to also examine the efficacy of new products available on the European market that stimulate growth and improve resilience and vitality among seedlings and saplings, with a view to the application of these products forming part of an integrated programme of plant protection. This paper describes trials of the three commercially available fertilizer products Actifos, Zielony Busz and Effective Microorganisms (EM), as carried out in seven Polish nurseries in an attempt to promote the growth of shoots and root systems of seedlings and saplings. In $64 \%$ of cases of it being used, Actifos was shown to stimulate growth significantly beyond control levels in the shoots of oak, beech, pine, spruce and alder saplings as well as the roots of young alders and oaks.

\section{KeY WORDS}

pesticide, Actifos, saplings, seedlings, nurseries

\section{INTRODUCTION}

Every year in Poland, forest nurseries produce more than 800 million seedlings, which are mainly barerooted. Conifers are usually grown during one or two seasons while broadleaved tree species are kept longer, even for three to four years. Poland's accession to the European Union and the associated opening up of borders between EU member states has given rise to a rapid growth in the trade of various products (plants included) and the establishment of new, invasive pathogens in Poland (Oszako and Orlikowski 2008). A particular threat to nursery material is posed by soil pathogens of the genus Phytophthora (Kozłowska et al. 1961), which includes around 100 new species described in just the last ten years (Brasier 2008).

Looking at a more general and broader view of the topicality and relevance of the study, the material present in and sold by nurseries should be free of 'harmful organisms', that is in accordance with an EU Directive, though more precise details are not given. However, by way of a regulation, more precise provisions may be laid down, with appropriate reference made to alien and invasive organisms. If this is not done, the threat to the 
sustainability of future tree stands is posed, since their health depends on the quality and condition of supplied seedlings, which is especially vulnerable to infections by such fungi newly creeping into Europe from Asia as Phytophthora spp., Dothistroma septosporum and Chalara fraxinea, to say nothing of roundworm pests like the pine wilt nematode Bursaphelenchus xylophilus. Such pathogens are often transferred with soil or growing media and water, but also with the nursery-grown seedlings of forest and/or ornamental trees.

Fungal pathogens of the genus Phytophthora are increasingly reported to be widespread, even in natural conditions with limited human interference revealing their presence in most seedlings and trees studied in both nurseries and stands (Orlikowski et al. 2006; Oszako and Orlikowski 2004; Oszako and Orlikowski 2005; Oszako et al. 2007; Oszako and Orlikowski 2008). Baker and Matkin (1978) stated that the aquatic organisms most often producing 'swimming spores' are Phytophthora species.

Limitation of the spread of pathogens is especially necessary at forest nurseries producing material for the use in forest reforestation. Pathogens escape to the forest plantations and forest practitioners lose the opportunity to control them. A connected issue in Poland is the restriction of the use of seed from a given region provided for in the Forest Reproductive Materials Act and executive regulations thereto, which do incidentally regulate transfers of seeds and saplings (Pigan 2009). To this end, the Institute of Forestry in Austria, for example, issued on the voluntary basis certifications that markedly increase the success on the market for plants for planting of those private nurseries that are demonstrably free of the above problems (Thomas Cech, pers. comm.).

Given the current very limited number of plant protection agents approved for the use in forestry by the Ministry of Agriculture and Rural Development, there is a great need to test and assess alternative preparations (not least resistance-enhancing fertilizers) - from the point of view of their efficacy in promoting growth, and /or resistance to forest pests.

The use of growth-stimulating preparations has been subjected to testing and these preparations are in use in gardens, orchards and ornamental nurseries in many European countries, as well as in the USA or South Africa (Glinicki et al. 2010; Malusa and Tosi
2005). In Poland, their activity as fungicides was tested by Bielenin (2002), Orlikowski (2004), Korzeniowski and Orlikowski (2008), Muszyńska and Orlikowski (2010), and Wieczorek et al. (2010). It is estimated that the number of products based on phosphites available on the market will be quickly growing and sold as fertilizers. Although active compounds inhibit the growth of mycelium, they rather seem to induce or enhance plant resistance (Hoang and Takeo 2009). In fact, phosphites are not fertilizers (if not amended with other macro- and micro-elements) and plants cannot absorb them directly in the form of $\mathrm{PO}_{3}{ }^{-}$ions but they circulate within plant vessels (in xylem) even for six to eight years (Hardy 1999). Phosphorus ions accumulate in external parts of plant organs like fine roots, and act there as elicitors of resistance processes taking place at the cell level. In orchards, their effectiveness against apple diseases caused by Venturia inaequalis (Bock et al. 2012), Penicillium expansum (Amiri and Bompeix 2011), Alternaria alternata (Sala et al. 2004) and pear pathogens as Venturia pirina, Phytophthora syringae pv. syringae was reported (Montesinos and Vilardell 2001; Moragrega et al. 1998). Grapes in wine yards are often protected by phosphites against Plasmopara viticola (Di Marco et al. 2011; Dufour and Corio-Costed 2013; Kelderer et al. 2006; Magarey et al. 1991; Speiser et al. 2000; Wicks et al. 1991) and Erysiphe necator (Dufour and Corio-Costed 2013), strawberries against (P. cactorum) black berries against $P$. cinnamomi and Pythium (Bryla et al. 2008).

The work described in this paper has thus sought to determine the effectiveness of the action of phosphite fertilizers, i.e. Actifos, Zielony Busz and Effective Microorganisms (EM) as bio-stimulators of the growth of saplings of pedunculate oak (Quercus robur L.), common beech (Fagus sylvatica L.), Scots pine (Pinus sylvestris L.), Norway spruce (Picea abies [L.] Karst.) and black alder (Alnus glutinosa Gaertn.). The proposed hypothesis presumes that in the soil of investigated nurseries, soil-borne phytopathogens are present. In such circumstances, the influence of commercially available bio-stimulators on the growth of several forest tree species was tested. The assumed hypothesis says that better stimulated the growing plants are, quicker is their reach to the development phase in which they are more resistant to the diseases occurring in nurseries. The relevant experiments to achieve this objective were carried out in seven forest nurseries distributed across Poland. 


\section{MATERIAL AND MEthOdS}

\section{Short description of the fertilizers used in the experiments}

The description on the label of the Actifos preparation (from the firm Agropak) suggests that it supplies plants with readily assimilable nitrogen and microelements capable of promoting growth, as well as a defined content of phosphite said to limit the development of certain diseases, notably powdery mildew of oak and the phytophthoroses. Actifos has ammonium phosphite as a key component (hence the simultaneous presence of $10 \%$ nitrogen), along with compounds supplying the microelements boron, copper, iron, manganese, molybdenum and zinc: $\mathrm{N}-10.2 \%$, B $0.02 \%$; $\mathrm{Cu} 0.008 \%$; Fe $0.06 \%$; Mn 0.04\%; Mo 0.004\%; Zn 0.02\%.

The Zielony Busz preparation (made by the firm Himal) is a mineral/organic fertilizer that can be applied to leaves and contains an adjuvant. It comprises of the so-called soap of potash as well as wormwood, garlic, nettle and algae extracts, thereby offering the microelements copper, cobalt, zinc, molybdenum, boron and other components. The principle of this fertilizer is the enhancement of plant resistance to physiological stresses. Studies carried out by the manufacturer suggested that the application on leaves of seedlings make them more robust and resistant to the activity of such harmful agents as pathogenic fungi. Content of $\mathrm{N}, \mathrm{P}$ and $\mathrm{K}$, in the mixture is: $\mathrm{N}-3 \% ; \mathrm{P}_{2} \mathrm{O}_{5}$ $-3 \% ; \mathrm{K}_{2} \mathrm{O}-2.5 \%$.

Effective Microorganisms (EM) is a mix of microorganisms of aerobic and anaerobic conditions that coexist by virtue of symbiosis. None of the preparations involving the $\mathrm{EM}^{\mathrm{TM}}$ technology contain genetically modified or chemical components used in the manufacture of fertilizers, herbicides or pesticides. The manufacturer Greenland Technologia offers an assurance that EM is naturally active in improving soil structure, encouraging the rapid breakdown of plant tissue residues, obstructing transfer processes involving soil pathogens, encouraging the fixing in the soil of free nitrogen present in the air, intensifying root-system development, engendering conditions for the better absorption of nutrients and thus improving the condition and health of plants that come into contact with it.

The main difference among preparations is that only Actifos contains ammonium phosphate $\left(\mathrm{NH}_{4}\right)_{3} \mathrm{PO}_{3}$.

\section{Study area and times at which measures were taken}

Comparisons regarding the effectiveness of the above preparation were made on the most important species of samplings growing in Polish forest nurseries (Tab. 1) within the eight forest districts of Borki, Giżycko, Toruń, Augustów, Przasnysz, Żednia, Koło, and Nowy Targ (Fig. 1). Plants were bare-rooted and sprayed twice with bio-stimulators at the beginning of vegetation season when leaves of broadleaved tree species were fully developed (in May and in June).

Table 1. List of studied, new bio-stimulators available in the Polish market, and species of plants tested in Forest Districts in which experiments were run

\begin{tabular}{|c|c|c|c|c|c|c|}
\hline \multirow[b]{2}{*}{$\begin{array}{c}\text { Forest } \\
\text { Districts }\end{array}$} & \multirow[b]{2}{*}{$\begin{array}{c}\text { Year of } \\
\text { measure- } \\
\text { ment }\end{array}$} & \multirow[b]{2}{*}{ Species } & \multirow[b]{2}{*}{ Age } & \multicolumn{3}{|c|}{ Application of } \\
\hline & & & & 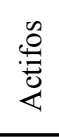 & 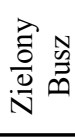 & 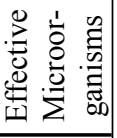 \\
\hline \multirow{3}{*}{ Augustów } & \multirow{3}{*}{2012} & Pine & 1 & $\mathrm{n} / \mathrm{d}$ & $\mathrm{n} / \mathrm{d}$ & yes \\
\hline & & Oak & 1 & $\mathrm{n} / \mathrm{d}$ & yes & $\mathrm{n} / \mathrm{d}$ \\
\hline & & Alder & 2 & $\mathrm{n} / \mathrm{d}$ & yes & $\mathrm{n} / \mathrm{d}$ \\
\hline \multirow{2}{*}{ Borki } & 2011 & Oak & 1 & yes & $\mathrm{n} / \mathrm{d}$ & $\mathrm{n} / \mathrm{d}$ \\
\hline & 2012 & Oak & 2 & yes & $\mathrm{n} / \mathrm{d}$ & $\mathrm{n} / \mathrm{d}$ \\
\hline \multirow{2}{*}{ Giżycko } & \multirow{2}{*}{2012} & Pine & 1 & yes & yes & $\mathrm{n} / \mathrm{d}$ \\
\hline & & Spruce & 1 & yes & yes & $\mathrm{n} / \mathrm{d}$ \\
\hline \multirow{2}{*}{ Koło } & 2011 & Alder & 1 & yes & $\mathrm{n} / \mathrm{d}$ & $\mathrm{n} / \mathrm{d}$ \\
\hline & 2012 & Alder & 2 & yes & $\mathrm{n} / \mathrm{d}$ & $\mathrm{n} / \mathrm{d}$ \\
\hline \multirow{2}{*}{ Przasnysz } & 2011 & Beech & 2 & yes & yes & yes \\
\hline & 2012 & Beech & 3 & yes & yes & yes \\
\hline $\begin{array}{l}\text { Nowy } \\
\text { Targ }\end{array}$ & 2011 & Alder & 2 & yes & $\mathrm{n} / \mathrm{d}$ & $\mathrm{n} / \mathrm{d}$ \\
\hline Toruń & 2012 & Oak & 2 & yes & $\mathrm{n} / \mathrm{d}$ & $\mathrm{n} / \mathrm{d}$ \\
\hline Żednia & 2011 & Oak & 2 & yes & $\mathrm{n} / \mathrm{d}$ & $\mathrm{n} / \mathrm{d}$ \\
\hline
\end{tabular}

yes - application; $\mathrm{n} / \mathrm{d}$ - no data; Pine - Scots pine (Pinus sylvestris L.); Spruce - Norway spruce (Picea abies [L.] Karst.); Oak - Pedonculate oak (Quercus robur L.); Beech - Common beech (Fagus sylvatica L.); Alder - Black alder (Alnus glutinosa Gaertn.).

At each of the nurseries, the researchers delimited both a study area across which the agents to be tested were sprayed, and a control area in which no treatments were applied. Plant material was then collected in 2011 and 2012. Table 1 presents the preparations that were used, in relation to different species, the year of collection of the material, and the Forest District (FD) in which the given experiment was run. 


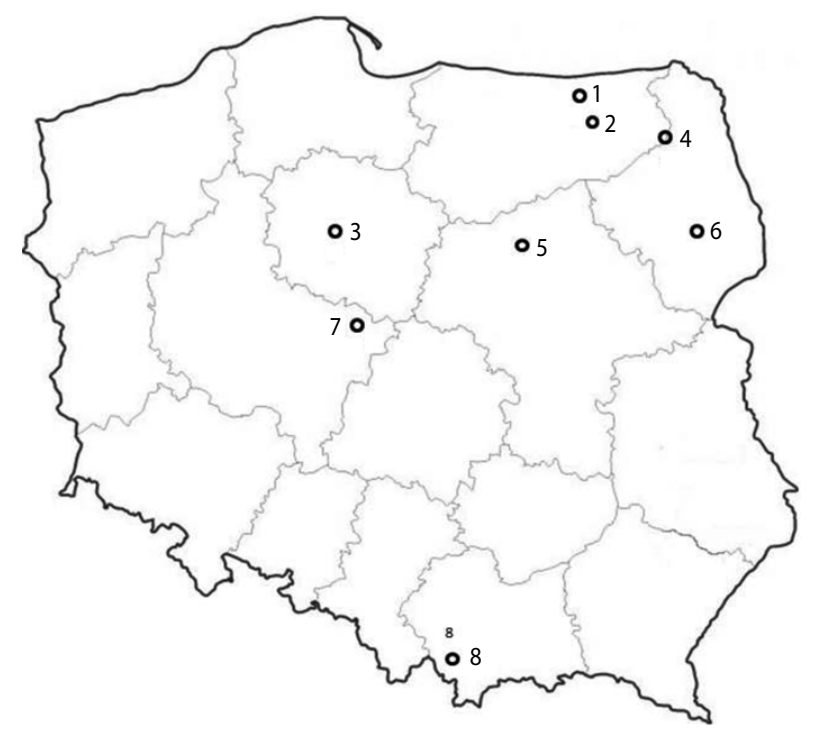

Figure 1. Map of Forest Districts in which the research was carried out

Measurements were done at the end of each vegetation season (September of 2011 and 2012). Each trial or control variant investigated on the delimited study plots was assessed by reference to 15 saplings collected in three replicates, the length of the aboveground parts being measured (from base to apex) along with the length of the tap root. The saplings of the most important forest tree species were treated, including conifers (Scots pine, Norway spruces) as well as broadleaved tree species (common beech, pedonculate oak and black alder).

Additionally, biomass of saplings from five FDs was assessed.

\section{Statistical analysis}

Research at the Karwacz (Przasnysz Forest District), Zielonki (Borki FD) and Kiejsze (Koło FD) nurseries was extended over the two years 2011 and 2012, while that at the remaining sites was confined to a single (2012) growing season. Measurements concerned the above-ground parts, as well as the length of the root system, in saplings selected at random, with data obtained allowing for the use of the non-parametric Mann-Whitney test, as well as one way ANOVA and the Kruskal-Wallis test, with adopted significance levels of $\alpha=0.05$. The Statistica v.10 package was used in the analysis.

\section{Results}

In six out of the 11 cases, saplings sprayed with Actifos responded with levels of growth in above-ground parts that exceeded those noted among plants maintained in the control conditions. The preparation had a positive effect on oaks, whose second-year growth of above-ground parts was greater in every variant as compared with the control. Two years of experimentation with beech evoked no reaction in the circumstances of Przasnysz FD, while in the case of black alders only two-year-old trees from the Nowy Targ FD displayed a reaction. A positive reaction of one-year-old pines and spruces to fertilizer use was also noted.

The Zielony Busz preparation was used at the three studied nurseries in Augustów, Giżycko and Przasnysz FDs. In three-fourth (75\%) of the cases, saplings reacted favourably to the foliar fertilizer application (spraying). A significant apparent boost to growth of above-ground

Table 2. Summary of the statistical analysis carried out on above-ground parts of investigated forest tree species saplings

\begin{tabular}{|c|c|c|c|c|c|c|c|}
\hline \multirow[b]{2}{*}{ 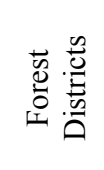 } & \multirow{2}{*}{ 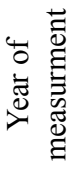 } & \multirow[b]{2}{*}{ 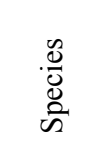 } & \multirow[b]{2}{*}{$\mathbb{8}_{4}^{\circ}$} & \multicolumn{4}{|c|}{ Average $[\mathrm{mm}]$} \\
\hline & & & & 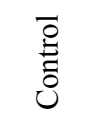 & 苞 & 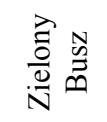 & $\sum_{I I}$ \\
\hline \multirow{3}{*}{$\begin{array}{l}\text { Augus- } \\
\text { tów }\end{array}$} & \multirow{3}{*}{2012} & Pine & 1 & 100.0 & $\mathrm{n} / \mathrm{d}$ & $\mathrm{n} / \mathrm{d}$ & $116.2^{+}$ \\
\hline & & Oak & 1 & 210.0 & $\mathrm{n} / \mathrm{d}$ & $314.8^{+}$ & $\mathrm{n} / \mathrm{d}$ \\
\hline & & Alder & 2 & 1503.6 & $\mathrm{n} / \mathrm{d}$ & $1751.3^{+}$ & $\mathrm{n} / \mathrm{d}$ \\
\hline \multirow{2}{*}{ Borki } & 2011 & Oak & 1 & 168.3 & 191.5 & $\mathrm{n} / \mathrm{d}$ & $\mathrm{n} / \mathrm{d}$ \\
\hline & 2012 & Oak & 2 & 392.4 & $442.7^{+}$ & $\mathrm{n} / \mathrm{d}$ & $\mathrm{n} / \mathrm{d}$ \\
\hline \multirow{2}{*}{$\begin{array}{l}\text { Giżyc- } \\
\text { ko }\end{array}$} & \multirow{2}{*}{2012} & Pine & \multirow{2}{*}{1} & 39.6 & $52.2^{+}$ & $74.7^{+}$ & $\mathrm{n} / \mathrm{d}$ \\
\hline & & Spruce & & 142.1 & $168.8^{+}$ & $166.7^{+}$ & $\mathrm{n} / \mathrm{d}$ \\
\hline \multirow{2}{*}{ Koło } & 2011 & Alder & 1 & 105.1 & 110.9 & $\mathrm{n} / \mathrm{d}$ & $\mathrm{n} / \mathrm{d}$ \\
\hline & 2012 & Oak & 2 & 1630.7 & 1778.8 & $\mathrm{n} / \mathrm{d}$ & $\mathrm{n} / \mathrm{d}$ \\
\hline \multirow{2}{*}{$\begin{array}{l}\text { Przas- } \\
\text { nysz }\end{array}$} & 2011 & Beech & 2 & 212.1 & 217.9 & 219.7 & 220.3 \\
\hline & 2012 & Beech & 3 & 475.8 & 485.9 & 573.7 & 547.4 \\
\hline $\begin{array}{l}\text { Nowy } \\
\text { Targ }\end{array}$ & 2011 & Oak & 2 & 95.7 & $86.0^{+}$ & $\mathrm{n} / \mathrm{d}$ & $\mathrm{n} / \mathrm{d}$ \\
\hline Toruń & 2012 & Pine & 2 & 733.6 & $676.4^{+}$ & $\mathrm{n} / \mathrm{d}$ & $\mathrm{n} / \mathrm{d}$ \\
\hline Żednia & 2011 & Oak & 2 & 174.6 & $226.6^{+}$ & $\mathrm{n} / \mathrm{d}$ & $\mathrm{n} / \mathrm{d}$ \\
\hline
\end{tabular}

* Forest administration Unit (c.a. 40000 ha of forest having own nursery of surface 5-10 ha); + Higher mean values for treatment plots (statistically significant differences); $\mathrm{n} / \mathrm{d}$ - no data; Pine - Scots pine (Pinus sylvestris L.); Spruce - Norway spruce (Picea abies [L.] Karst.); Oak - Pedonculate oak (Quercus robur L.); Beech - Common beech (Fagus sylvatica L.); Alder - Black alder (Alnus glutinosa Gaertn.). 
parts was to be observed among one-year-old oaks, two-year-old alders and one-year-old pines and spruces (Tab. 2). A lack of statistically significant boosts to growth was again noted for the shoots of beech.

The EM applied at the nurseries in Augustów and Przasnysz was found to have stimulated growth of the above-ground parts of one-year-old Scots pine saplings. However, no such effects could be noted with the treatments applied to young beeches (Tab. 2).

The second part of the experimental work involved a comparison of the dimensions to below-ground parts of saplings on experimental and control plots (Tab. 3). In this context, Actifos only emerged as effective in four variants involving: one-year-old saplings of black alder from Koło Forest District, one-year-old saplings of Scots pine and Norway spruce from Giżycko FD and two-year-old pedunculate oaks from Żednia FD. In other cases, there were no statistically significant differences to be noted between root lengths under treatment and control conditions (Tab. 3).

Spraying with the Zielony Busz preparation only impacted significantly upon two-year-old black alder seedlings, though these had their root systems twinned in the same year that measurements were made. So this fact may have accounted for the differences referred to. Under other variants, neither Zielony Busz nor the Effective Microorganisms were found to influence the dimensions of below-ground parts significantly.

In line with standard practice, in 2012, the saplings at the Augustów, Koło, Borki and Przasnysz nurseries were made subject to the same root-trimming measure, which eliminated any visible favourable impact on root-growth attributable to the use of the preparations.

Significant statistical differences for average above-ground part biomass was denoted in the case of Actifos in Giżycko FD (pine) and Przasnysz FD (beech), while this preparation was not effective for spruce, alder and oak in Giżycko, Koło and Torun FDs, respectively. Less effective appeared to be Zielony Busz and Effective Microorganisms preparations, which shown positive effect only in Giżycko (spruce) and Przasnysz (beech) FDs, respectively (Tab. 4).

As regards roots, Actifos was also the most effective preparation and significantly different from the control in pine and spruce (Giżycko FD), and beech saplings (Przasnysz FD). The effect of other prepara-
Table 3. Summary of statistical analysis for roots of investigated forest tree species saplings

\begin{tabular}{|c|c|c|c|c|c|c|c|}
\hline \multirow[b]{2}{*}{ 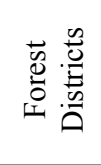 } & \multirow{2}{*}{ 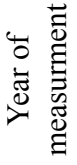 } & \multirow[b]{2}{*}{$\begin{array}{l}\mathscr{U} \\
\frac{\tilde{U}}{0} \\
\tilde{\Xi}\end{array}$} & \multirow[b]{2}{*}{$\stackrel{8}{80}$} & \multicolumn{4}{|c|}{ Average $[\mathrm{mm}]$} \\
\hline & & & & 嶽 & 先 & 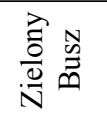 & $\sum_{I I}$ \\
\hline \multirow{3}{*}{$\begin{array}{l}\text { Augus- } \\
\text { tów }\end{array}$} & \multirow{3}{*}{2012} & Pine & 1 & 166.6 & $\mathrm{n} / \mathrm{d}$ & $\mathrm{n} / \mathrm{d}$ & 168.1 \\
\hline & & Oak & 1 & 330.8 & $\mathrm{n} / \mathrm{d}$ & 350.8 & $\mathrm{n} / \mathrm{d}$ \\
\hline & & Alder & 2 & 275.7 & $\mathrm{n} / \mathrm{d}$ & $279.8^{+*}$ & $\mathrm{n} / \mathrm{d}$ \\
\hline \multirow{2}{*}{ Borki } & 2011 & Oak & 1 & 199.1 & 240.1 & $\mathrm{n} / \mathrm{d}$ & $\mathrm{n} / \mathrm{d}$ \\
\hline & 2012 & Oak & 2 & 384.1 & $358.9^{*}$ & $\mathrm{n} / \mathrm{d}$ & $\mathrm{n} / \mathrm{d}$ \\
\hline \multirow{2}{*}{$\begin{array}{l}\text { Giżyc- } \\
\text { ko }\end{array}$} & \multirow{2}{*}{2012} & Pine & \multirow{2}{*}{1} & 116.7 & $148.7^{+}$ & 122.3 & $\mathrm{n} / \mathrm{d}$ \\
\hline & & Spruce & & 145.0 & $184.3^{+}$ & 157.2 & $\mathrm{n} / \mathrm{d}$ \\
\hline \multirow{2}{*}{ Koło } & 2011 & Alder & 1 & 302.0 & $366.2^{+}$ & $\mathrm{n} / \mathrm{d}$ & $\mathrm{n} / \mathrm{d}$ \\
\hline & 2012 & Oak & 2 & 405.9 & $338.1^{*}$ & $\mathrm{n} / \mathrm{d}$ & $\mathrm{n} / \mathrm{d}$ \\
\hline \multirow{2}{*}{$\begin{array}{l}\text { Przas- } \\
\text { nysz }\end{array}$} & 2011 & Beech & 2 & 330.5 & 243.4 & 468.6 & 218.0 \\
\hline & 2012 & Beech & 3 & 275.2 & $286.2^{*}$ & $250.0^{*}$ & $267.8^{*}$ \\
\hline $\begin{array}{l}\text { Nowy } \\
\text { Targ }\end{array}$ & 2011 & Oak & 2 & 159.7 & 163.0 & $\mathrm{n} / \mathrm{d}$ & $\mathrm{n} / \mathrm{d}$ \\
\hline Toruń & 2012 & Pine & 2 & 324.1 & $324.8^{*}$ & $\mathrm{n} / \mathrm{d}$ & $\mathrm{n} / \mathrm{d}$ \\
\hline Żednia & 2011 & Oak & 2 & 222.8 & $276.1^{+}$ & $\mathrm{n} / \mathrm{d}$ & $\mathrm{n} / \mathrm{d}$ \\
\hline
\end{tabular}

+ Higher mean values of the treatment plot (differences statistically significant); * cut root system, n/d - no data; Pine - Scots pine (Pinus sylvestris L.); Spruce - Norway spruce (Picea abies [L.] Karst.); Oak - Pedonculate oak (Quercus robur L.); Beech - Common beech (Fagus sylvatica L.); Alder - Black alder (Alnus glutinosa Gaertn.).

Table 4. Summary of statistical analysis for dry-biomass of above-ground parts of saplings

\begin{tabular}{|c|c|c|c|c|c|c|}
\hline \multirow[b]{2}{*}{$\begin{array}{c}\text { Forest } \\
\text { Districts }\end{array}$} & \multirow{2}{*}{ 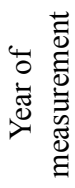 } & \multirow[b]{2}{*}{$\begin{array}{l}\tilde{0} \\
\frac{0}{0} \\
\stackrel{0}{0}\end{array}$} & \multirow[b]{2}{*}{$\underset{8}{80}$} & \multicolumn{3}{|c|}{ Application of } \\
\hline & & & & 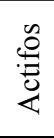 & 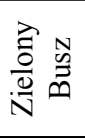 & 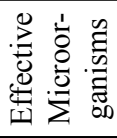 \\
\hline \multirow{3}{*}{ Augustów } & \multirow{3}{*}{2012} & Pine & 1 & $\mathrm{n} / \mathrm{d}$ & $\mathrm{n} / \mathrm{d}$ & - \\
\hline & & Oak & 1 & $\mathrm{n} / \mathrm{d}$ & - & $\mathrm{n} / \mathrm{d}$ \\
\hline & & Alder & 2 & $\mathrm{n} / \mathrm{d}$ & - & $\mathrm{n} / \mathrm{d}$ \\
\hline \multirow{2}{*}{ Giżycko } & \multirow{2}{*}{2012} & Pine & 1 & + & - & $\mathrm{n} / \mathrm{d}$ \\
\hline & & Spruce & 1 & - & + & $\mathrm{n} / \mathrm{d}$ \\
\hline Koło & 2012 & Alder & 2 & - & $\mathrm{n} / \mathrm{d}$ & $\mathrm{n} / \mathrm{d}$ \\
\hline Przasnysz & 2012 & Beech & 3 & + & - & + \\
\hline Toruń & 2012 & Oak & 2 & - & $\mathrm{n} / \mathrm{d}$ & $\mathrm{n} / \mathrm{d}$ \\
\hline
\end{tabular}

+ Higher mean values of the treatment plot (differences statistically significant); - Differences no statistically significant; * cut root system, $\mathrm{n} / \mathrm{d}$ - no data. 


\section{DE GRUYTER}

OPEN

tions was limited merely for spruce (Giżycko FD) and beech (Przasnysz FD) (Tab. 5).

Table 5. Summary of statistical analysis for dry-biomass of sapling roots

\begin{tabular}{|c|c|c|c|c|c|c|}
\hline \multirow[b]{2}{*}{$\begin{array}{c}\text { Forest } \\
\text { Districts }\end{array}$} & \multirow{2}{*}{ 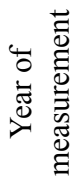 } & \multirow[b]{2}{*}{$\begin{array}{l}\mathscr{0} \\
\frac{\tilde{D}}{0} \\
\text { के }\end{array}$} & \multirow[b]{2}{*}{$\underset{4}{\infty}$} & \multicolumn{3}{|c|}{ Application of } \\
\hline & & & & 莺 & 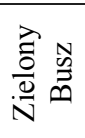 & 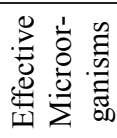 \\
\hline \multirow{3}{*}{ Augustów } & \multirow{3}{*}{2012} & Pine & 1 & $\mathrm{n} / \mathrm{d}$ & $\mathrm{n} / \mathrm{d}$ & - \\
\hline & & Oak & 1 & $\mathrm{n} / \mathrm{d}$ & - & $\mathrm{n} / \mathrm{d}$ \\
\hline & & Alder & 2 & $\mathrm{n} / \mathrm{d}$ & - & $\mathrm{n} / \mathrm{d}$ \\
\hline \multirow{2}{*}{ Giżycko } & \multirow{2}{*}{2012} & Pine & 1 & + & - & $\mathrm{n} / \mathrm{d}$ \\
\hline & & Spruce & 1 & + & + & $\mathrm{n} / \mathrm{d}$ \\
\hline Koło & 2012 & Alder & 2 & - & $\mathrm{n} / \mathrm{d}$ & $\mathrm{n} / \mathrm{d}$ \\
\hline Przasnysz & 2012 & Beech & 3 & + & - & + \\
\hline Toruń & 2012 & Oak & 2 & - & $\mathrm{n} / \mathrm{d}$ & $\mathrm{n} / \mathrm{d}$ \\
\hline
\end{tabular}

+ Higher mean values of the treatment plot (differences statistically significant); - Differences no statistically significant; * cut root system, $\mathrm{n} / \mathrm{d}$ - no data.

\section{Discussion}

In light of current knowledge on the occurrence and diversity of pathogens of forest nurseries as Phytophthora species, as well as the limited arsenal of plant protection agents whose use is currently permitted, it seems crucial to seek alternatives, not least in the form of fertilizer preparations that can stimulate growth, as well as phosphite-containing products considered to enhance plant resistance (Jung 2008; Orlikowski et al. 2004a; Orlikowski et al. 2004b; Oszako 2005; Oszako and Orlikowski 2008; Orlikowski et al. 2011). The present research also proved that phosphites are valuable fungicides (mainly against Phytophthora) and bio-stimulators of plant growth. Originally the effect of fertilization on seedlings resistance to pathogens was planned by evaluating plant health but this key measurement did not show any difference between variants of the experiments. Probably, the time span of the tests was too short or the weather and stress conditions were not so strong to weaken plants for planting. In fact, there was no mortality observed in any of the experimental plots. For this reason, we have to focus on the effect of these fertilizers on seedling growth by assessing mainly stem height and tap root length as well as total biomass split into the weight of the above and below organs. The dry mass of leaves / needles was included into the stem measurements. Because the effect of other commercial fertilizers traditionally applied in forest nurseries is well known, they were not tested in these trials, which move us beyond what is already known.

However, their effectiveness as regards the main forest-forming tree species initially raised in forest nurseries had not been tested until now, in the context of the work described here. Our research carried out revealed that the most effective of the tested preparations was Actifos, which has a clear impact on the growth of both stems and roots, and can therefore serve as a valuable supplementary agent in the system of integrated plant protection deployed at forest nurseries. While plants furnished more fully with mineral nutrients (especially microelements) grow better and are more disease-resistant, we do not know how phosphite fertilizers act in situations where the saplings have already been infected. In theory, the seriousness of the attack mounted by soil pathogens could be reduced through the protection of the fine roots and a reduction in the level of mortality among saplings. But is total healing of infected plants possible, or is it merely a question of masking disease? These questions will only be answered satisfactorily if further studies are pursued. In the course of the work, it was also possible to observe that oak leaves treated with phosphite preparation were less afflicted by the powdery mildew caused by Erysiphe alphitoides, and this is a further observation meriting dedicated study. We do not know why Actifos did not stimulate growth of beech shoots and roots in Przasnysz FD, as well as oneyear-old oaks in Borki FD. Probably, positive effect of the bio-stimulator was altered by the trimming of main roots or more time was needed to obtain the significant difference from control variants.

It is also worth reconsidering the merits of the nursery measure entailing the trimming of main roots with the aim of stimulating the development of finer sideroots. Open wounds that may even be of $3 \mathrm{~cm}$ diameter (as in the case of a black alder in Koło FD) offer ready access to infection by pathogens (Mańka 1998), while the combined wounding arising out of all the damage to different roots represents a major challenge to the plant in terms of the expenditure of energy and nutri- 
ents incurred to develop the necessary scar tissue. Furthermore, resort to this kind of measure gives rise to disproportions between the dimensions of the root system, on the one hand, and the above-ground parts, on the other (stems may even be 10 times as long as roots). This also has a negative impact on the survival chances of saplings once they are planted out.

Root-trimming is supposed to help several-yearold saplings of broadleaved species with tap roots (like oak) to be collected before transport. In contrast, it may be indicated (also from the economic point of view) to grow the young trees in nurseries for shorter periods, and not to trim their roots. Achievement of the saplings of the necessary dimensions can be assured through the appropriate use of growth-stimulating agents. Saplings planted out in an undamaged state will then be more resistant to the swimming spores of pathogenic Phytophthora species, should soils become very wet; and they will also be more likely to survive periods of drought if they have an appropriate distribution of biomass between above- and below-ground parts.

From among the preparations used, it was Actifos that emerged as the most effective. In $64 \%$ of the cases in which it was applied, it was possible to note a positive influence as compared with controls where the length of above-ground parts of oak, beech, pine, spruce and alder saplings was concerned. A similar effect was to be noted for roots, though statistical significance was only obtained in the cases of alder and oak. In contrast, there was one case of the use of Actifos (within Torun FD) in which the growth and development of two-year-old pedunculate oak saplings was poorer than in the control.

The routine procedure of root-trimming carried out at nurseries prior to measurement of growth in saplings of pedunculate oak (in Torun and Borki FDs), common beech (in Przasnysz FD) and black alder (in Koło FD) made it impossible to assess differences in lengths of the root systems between fertilizer-treated and control plants. In this light, the need for mechanical trimming of root systems at nurseries should be reconsidered, since the wounds arising in this way must heal (at great cost in terms of energy) and evidently constitute a pathway for infection by a range of pathogens.

The other tested preparations proved less effective at promoting below-ground growth, while Zielony Busz was able to encourage above-ground growth in saplings in about $66 \%$ of the cases in which it was used. The only saplings not showing a response were young beeches in Przasnysz FD.

Biomass and root-collar diameter (RCD) are even better than length measurements for effectiveness evaluation of bio-stimulator fertilizers. In the case of our experiments, the Actifos most effectively stimulated the shoot and root biomass of broadleaved and conifer saplings. The above indicators well reflect growth and health state of saplings in nurseries.

The costs of the use of these products are comparable, however the cheapest product is Zielony Busz ( $3 € / 1)$, while Effective Microorganisms $(8 € / 1)$ is the most expensive, depending on the concentrations of the bio-stimulators: Actifos 0.6\%, Zielony Busz 2-5\%, but when the plant blooms the concentration can be reduced to $0.5 \%$, and for EM to $0.06 \%$. Usually, manufacturers recommend applying those working solutions per hectare as follows: 6001 for Actifos, 601 for EM, and 5001 for Zielony Busz. The amount of labor to spray products is also similar as we recommend using them twice or three times during vegetation season (e.g. in June and July, or additionally in August).

\section{Acknowledgements}

The research was financed by the Grant no DNP/N157/ COST/2009 of the Ministry of Science and Higher Education, ISEFOR Grant UE no 245268 7FP: Increasing Sustainability of European Forests: Modelling for Security Against Invasive Pests and Pathogens under Climate Change, and grant NCBiR NR12-0098-10 of the Ministry of Science and Higher Education.

\section{References}

Amiri A., Bompeix G. 2011. Control of Penicillium expansum with potassium phosphite and heat treatment. Crop Protection, 30, 222-227.

Baker K.F., Matkin O.A. 1978. Detection and control of pathogens in water. Ornamentals Northwest Newsletter, 2, 2-14.

Bielenin A. 2002. Grzyby z rodzaju Phytophthora w uprawach sadowniczych: występowanie, szkodliwość i zwalczanie. Zeszyty Naukowe Instytutu 
Sadownictwa i Kwiaciarstwa. Monografie i Rozprawy. Skierniewice, Poland.

Bock C.H., Brenneman T.B., Hotchkiss M.W., Wood B.W. 2012. Evaluation of the phosphite fungicide to control pecan scab in the southeastern USA. Crop Protection, 36, 58-64.

Brasier C.M. 2008. The biosecurity threat to the UK and global environment from international trade in plants. Plant Pathology, 57, 792-808.

Bryla D.R., Linderman R.G., Yang W.Q. 2008. Incidence of Phytophthora and Pythium infection and the relation to cultural conditions in commercial blueberry fields. HortScience, 43 (1), 260-263.

Di Marco S., Osti F., Calzarano F., Roberti R., Veronesi A., Amalfitano C. 2011. Effects of grapevine applications of fosetyl-aluminium formulations for downy mildew control on "esca" and associated fungi. Phytopathologia Mediterranea, 50, 285-299.

Dufour M.C., Corio-Costed M.F. 2013. Variability in the sensitivity of biotrophic grapevine pathogens (Erysiphe necator and Plasmopara viticola) to acibenzolar - S methyl and two phosphonates. European Journal of Plant Pathology, 136, 247-259.

Glinicki R., Sas-Paszt L., Jadczuk-Tobjasz E. 2010. The effect of plant stimulant / fertilizer "RESISTIM" on growth and development of strawberry plants. Journal of Fruit and Ornamental Plant Research, 18, 111-124.

Hardy G.E.St.J. 1999. Phosphite and its potential to control P. cinnamomi in natural plant communities and adjacent rehabilitated mine sites in Western Australia. In: First International Meeting on Phytophthoras in Forest and Wildland Ecosystems - Phytophthora Diseases of Forest Trees, IUFRO Working Party 7.02.09, August 30 - September 3, 1999, Grants Pass, Oregon USA, 82-86.

Hoang T.B.T., Takeo Y. 2009. Phosphite (phosphorous acid): Fungicide, fertilizer or biostimulator? Soil Science and Plant Nutrition, 55, 228-234.

Jung T. 2008. Widespread Phytophthora infestations of nursery stock in Central Europe as major pathway of Phytophthora diseases of forests and seminatural ecosystems. 3rd International Workshop Phytophthora/Pythium and related genera. 9th Congress of Plant Pathology, Turin, Italy, August 24-29, 2008.
Kelderer M., Matteazzi A., Casera C. 2006. Effects of the period of application of K-phosphite on residues on apple fruits, Ecofruit - 12th International Conference on Cultivation Technique and Phytopathological Problems in Organic Fruit-Growing. Proceedings to the Conference from $31^{\text {st }}$ January to $2^{\text {nd }}$ February 2006 at Weinsberg/Germany, 225-227.

Korzeniowski M., Orlikowski L.B. 2008. Ochrona różanecznika przed fytoftorozą (Phytophthora spp.) środkami zawierającymi fosetyl glinowy, propamokarb i fenamidon. Zeszyty Problemowe Postępów Nauk Rolniczych, 529, 35-39.

Kozłowska C., Brennejzen B., Benben K. 1961. Stan zagrożenia lasów polskich przez ważniejsze choroby pochodzenia grzybowego. Prace Instytutu Badawczego Leśnictwa, 266, 47-56.

Magarey P.A., Wachtel M.F., Newton M.R. 1991. Evaluation of phosphonate, fosetyl-Al and several phenylamide fungicides for post-infection control of grapevine downy mildew caused by Plasmopara viticola. Australasian Plant Pathology, 20, 34-40.

Malusa E., Tosi L. 2005. Phosphorous acid residues in Apple after foliar fertilization: Results of field trials. Food Additives and Contaminants, 22, 541-548.

Mańka K. 1998. Fitopatologia leśna. Państwowe Wydawnictwo Rolnicze i Leśne. Warszawa, Poland, 112-150.

Montesinos E., Vilardell P. 2001. Effect of bactericides, phosphonates and nutrient amendments on blast of dormant flower buds of pear: a field evaluation for disease control. European Journal of Plant Pathology, 107, 787-794.

Moragrega C., Manceau C., Montesinos E. 1998. Evaluation of drench treatments with phosphonate derivatives against Pseudomonas syringae pv. syringae on pear under controlled environment conditions. European Journal of Plant Pathology, 104, 171-180.

Muszyńska D., Orlikowski L.B. 2010. Wykorzystanie propamokarbu $\mathrm{z}$ fosetylem glinowym $\mathrm{w}$ ochronie cyprysika i pelargonii przed Phytophthora cinnamomi i Pythium ultimum. Zeszyty Problemowe Postępów Nauk Rolniczych, 554, 113-118.

Orlikowski L.B. 2004. Chemical control of Rhododendron twig blight caused by Phytophthora ramorum. Journal of Plant Protection Research, 44 (1), 41-46. 
Orlikowski L.B., Duda B., Szkuta G. 2004a. Phytophthora citricola on European beech and Silver fir in Polish forest nurseries. Journal of Plant Protection Research, 44, 57-64.

Orlikowski L.B., Oszako T., Duda B., Szkuta G. 2004b. Występowanie Phytophthora na jesionie wyniosłym (Fraxinus excelsior) w szkółkach leśnych. Leśne Prace Badawcze, 4, 129-136.

Orlikowski L.B., Oszako T., Ptaszek M. 2011. Zagrożenia szkółek leśnych przez gatunki Phytophthora. Sylwan, 155 (5), 322-329.

Orlikowski L.B., Oszako T., Szkuta G. 2006. First record of Phytophthora spp. associated with the decline of European beech stand in south-west Poland. Phytopathologia Polonica, 42, 37-46.

Oszako T. 2005. Zagrożenie szkółek i drzewostanów, ze szczególnym uwzględnieniem olszy przez gatunki z rodzaju Phytophthora. Sylwan, 6, 55-61.

Oszako T., Orlikowski L.B., Trzewik A. 2007. Zagrożenie polskich szkółek leśnych przez gatunki rodzaju Phytophthora. Progress in Plant Protection, 47 (2), 224-234.

Oszako T., Orlikowski L.B. 2004. The first noting of Phytophthora citrophthora on Picea abies in a forest stand. Phytopathologia Polonica, 34, 81-85.

Oszako T., Orlikowski L.B. 2005. Pierwsze dane o występowaniu Phytophthora cinnamomi na dębie szypułkowym w Polsce. Sylwan, 149 (10), 47-53.
Oszako T., Orlikowski L.B. 2008. Fytoftoroza siewek modrzewia - występowanie i szkodliwość. Progress in Plant Protection, 48 (2), 491-494.

Pigan M. 2009. Kierunki Rozwoju Szkółkarstwa w Lasach Państwowych na lata 2009-2015. Zarządzenie 27/2009. Biuletyn Informacyjny Lasów Państwowych, Warszawa.

Sala F.C., Da Costa C.P., De Moraes Echer M., Martins M.C. 2004. Blat, S.F. Phosphite effect on hot and sweet pepper reaction to Phytophthora capsici. Scientia Agricola, 61, 492-495.

Speiser B., Berner A., Häseli A., Tamm L. 2000. Control of downy mildew of grapevine with potassium phosphonate: Effectivity and phosphonate residues in wine. Biological Agriculture and Horticulture, 17, 305-312.

Wicks T.J., Magarey P.A., Wachtel M.F., Frensham A.B. 1991. Effect of post-infection application of phosphorous (phosphonic) acid on the incidence and sporulation of Plasmopara viticola on grapevine. Plant Disease, 75, 40-43.

Wieczorek W., Orlikowski L.B., Świętosławski J., Ptaszek M. 2010. Nowy fosforyn do ochrony roślin ozdobnych przed gatunkami Phytophthora. Zeszyty Problemowe Postępów Nauk Rolniczych, 554, 277-283. 